Acta vet. scand. $1971,12,297-299$.

Brief Communication

\title{
THE OCCURRENCE OF WHIRLING DISEASE (MYXOSOMIASIS) IN NORWAY
}

Whirling disease caused by Myxosoma cerebralis is a widespread and feared disease in fingerlings of hatchery reared rainbow trout (Salmo gairdneri). Since the first description of Whirling disease (Hofer 1903), it has been diagnosed in many countries in and outside Europe.

In Norway whirling disease was first detected in 1970. Investigations, however, showed that the disease probably had existed for several years in a fish farm near Oslo without confirmation of the diagnosis.

In the following a short description is given of whirling disease in rainbow trout in connection with outbreaks of the disease in three Norwegian fish farms.

The disease was first diagnosed in a freshwater fish farm in connection with an inspection of the farm required by the Norwegian fish disease legislation. A great deal of the fry that were held in earth ponds showed blackened tail, deformities of the vertebral columns, misshapen heads with shortened gill covers and shortened, twisted lower jaw. Some of the fishes had a tendency to whirling movements. The mortality was minimal, probably because the fry had been held in glassfiber-armed plastic throughs until they reached a length of 5-10 cm beforé they were stocked in earth ponds. Previously the fry had been transferred directly from the hatching troughs to the earth ponds with a resulting heavy mortality. The older fish in the farm (fingerlings to brood fish) showed more or less the same pathological picture as described above, but the frequency of misshapen fish was not so high. Except for the protracted stocking of the earth ponds, nothing had been done to control the disease.

The disease was spread to two other fish farms which had bought 5000 fingerlings each from the fish farm mentioned above. In these farms there were heavy losses of fish the first 
two days after the transportation; the mortality was estimated at 5-600. After this initial mortality, the death rate was about 15-20 fish per day in the following two months before fishpathologists were informed. In October 1970 the National Veterinary Institute received some fingerlings from these farms located on the western coast of Norway. In accompanying letters, the owners told that the fish had not gained sufficient weight compared with other fishes in the farms and some fish had twisting movements, black tails, twisted spines and deformed heads with shortened gill covers. The shortened gill cover had resulted in Saprolegnia infection of the gills.

The diagnosis in the three cases was confirmed by the demonstration of spores and trophozoites in the cartilaginous tissue of the head. As method the scraping technique (Hoffman et al. 1968) was used. The scrapings from the cut surfaces were partly mounted as wet preparations in a drop of sterile saline, partly in glycerin albumen. The wet mount preparations were examined at once, while the glycerin albumen preparations were allowed to dry and then stained with May-Grünwald-Giemsa and Hematoxyline-Eosin.

As no effective treatment exists for control of the disease, necessary steps to avoid further spread of the disease were taken according to the Norwegian fish disease legislation. These steps included prohibition of selling live fish to other fish farms and for stocking to natural waters until the diseased fish had been destroyed and ponds, trough, and equipment had been thoroughly disinfected.

\section{DISCUSSION}

The symptoms, pathological changes and the parasitological findings described above, are in accordance with the characteristics of whirling disease caused by Myxosoma cerebralis (Ghittino 1962; Hoffman et al. 1962; Uspenskaya 1955). It can therefore be concluded that the disease described above is whirling disease.

This is believed to be the first incidence of whirling disease reported from Norway.

In two of the described cases the disease was introduced to the fish farms with fry from an infected hatchery, while in the first case the infection route is unknown. As no therapy is possible, the disease has to be controlled by sanitary means, in- 
cluding destruction of the diseased fish and disinfection of ponds, troughs and equipment.

Tore Håstein

The National Veterinary Institute, Oslo, Norway.

\section{REFERENCES}

Ghittino, P.: Le principali malattie dei pesci. (The principal diseases of fish). Lezione tenute al „IX Corso Teorico-pratico per Veterinari sulla Ispezione Sanitaria, Industria e Commercio dei Prodotti della Pesca“. Pescara 1962, 23 luglio-6 novembre, 35 pp. Grafico F Lli Lega, Faenza.

Hofer, B.: UUber die Drehkrankheit der Regenbogenforelle. (The whirling disease of rainbow trout). Allg. Fish Ztg. 1903, 28, no. 1, $7-8$.

Hoffman, G. L., C. E. Dunbar \& A. Bradford: Whirling disease of trout caused by Myxosoma cerebralis in the United States. U. S. Fish Wildlife Serv. Spec. Sci. Rep. Fish 1962, 427, 15-17.

Hoffman, G. L., S. F. Snieszko \& K. Wolf: Approved procedure for determining absence of viral hemorrhagic septicemia and whirling disease in certain fish and fish products. U.S. Dept. Interior. Bur. Sport Fish. Wildlife, Wash. DC 1968, FDL-9, 7 pp.

Uspenskaya, A. V.: Biology, distribution and economic importance of Myxosoma cerebralis, the causative agent of whirling disease of trout. Lect. Acad. Sci. USSR 1955, 105, 1132-1135.

(Received April 26. 1971). 